IVANA DOBRIVOJEVIĆ, naučni saradnik

Institut za savremenu istoriju

UDK 351.778.5(497.1)"1945/1955"(093.2)

Beograd, Trg Nikole Pašića 11

$349.444(497.1) " 1945 / 1955 "(093.2)$

\title{
STAMBENE PRILIKE U JUGOSLOVENSKIM GRADOVIMA 1945-1955*
}

\begin{abstract}
APSTRAKT: U članku se razmatraju teške stambene prilike u jugoslovenskim gradovima za vreme prve posleratne decenije. Posebna pažnja je posvećena nedovoljnoj i nekvalitetnoj stanogradnji, odnosu prema stambenom fondu i instituciji zajedničkog stana. Korišćena građa se čuva u Arhivu Jugoslavije, Arhivu Srbije, Istorijskom arhivu Beograda, Istorijskom arhivu Pančeva i Međuopštinskom istorijskom arhivu Valjeva.
\end{abstract}

Ključne reči: Jugoslavija, Komunistička partija, urbanizacija, stanogradnja, zajednički stan

Ubrzana industrijalizacija, partijska politika prema selu i seljaštvu, ali i relativna agrarna prenaseljenost, doveli su gotovo odmah po završetku Drugog svetskog rata do dinamizovanja urbanizacijskih procesa u Jugoslaviji. Migracije ka gradovima su, posebno od 1953. godine, sve više dobijale na intenzitetu i poprimale obrise istinske „seobe naroda“. ${ }^{1}$ Upravo kao i na Zapadu, iskorak u urbano društvo desio se za života jedne generacije, ${ }^{2}$ pa se, prema nekim procenama demografa, samo do 1953. u jugoslovenske gradove se doselilo čak milion novih žitelja. ${ }^{3}$ Naglo narasli gradovi suočavali su se sa brojim komunalno-infrastrukturnim problemima od kojih je jedan od najtežih, i pokazaće se, nerešivih, predstavljala dramatična oskudica stanova. Nedostatak osnovnog životnog prostora presudno je uticao na

* Rad je deo projekta Srpsko društvo u jugoslovenskoj državi u 20. veku: između demokratije i diktature (177016) koje finansira Ministarstvo prosvete, nauke i tehnološkog razvoja Republike Srbije.

${ }^{1}$ I. Ginić, Dinamika i struktura gradskog stanovništva Jugoslavije. Demografski aspekti urbanizacije, Beograd 1967,

${ }^{2}$ L. Wirth, Urbanism as a Way of Life, Urban Life. Readings in Urban Anthropology (edited by G. Gmelch, W. Zenner) Prospect Heights 1996, 15.

${ }^{3}$ Stanovi, A JBT, KPR III-A-1-b. V. i D. Stefanović, Stambena izgradnja i njeno finansiranje u gradovima FNRJ, Ekonomist, 1, 1955, 50. 
na kvalitet i kulturu življenja, doprinosio daljoj ruralizaciji gradova, ali i ugrožavao privatnost velikog broja građana. Stambeni fond, oskudan i u predratnim prilikama, teško je stradao za vreme rata. Obnova kuća i stanova je išla sporo, a preglomazni objekti teške industrije gutali su i ono malo finansijski sredstava koja su bila na raspolaganju.

"Zvaničan" završetak obnove 1947. godine stanovnicima jugoslovenskih grada nije mnogo doneo. Opravku oštećenih zgrada je, osim finansijskih problema i nestašice osnovnog građevinskog materijala, usporavala i kočila državna politika preniskih kirija, budući da je velik deo stambenih zgrada, naročito u Beogradu, između dva rata podizan isključivo radi izdavanja. Usled neprestanog povećavanja troškova održavanja i uvođenja raznih dažbina, rentabilitet starih zgrada u prestonici „spustio se na oko $1 \%$ neto" ili ga uopšte i nije bilo. ${ }^{4} \mathrm{U}$ ovakvim okolnostima, nekadašnji vlasnici, i sami osiromašeni u ratu, nisu imali mnogo razloga da ulažu u oprav$\mathrm{ku}$ stambenog fonda. Štaviše, maloj motivisanosti predratnih rentijera doprinosila je i politička klima u kojoj je nekadašnji građanski sloj bio izložen stalnim sumnjičenjima, pretnjama i prozivanjima, a privatno vlasništvo, formalno zagarantovano Ustavom iz 1946. godine, ${ }^{5}$ podložno konfiskacijama i nacionalizaciji. Ekonomskim upropašćavanjem nekadašnje elite, država je postala vlasnik velikog broja stambenih zgrada, pa se samo u Beogradu u državnim rukama do proleća 1946. našlo čak 12.000 stanova. ${ }^{6}$

Vlasti su pokušale da administrativnim merama, preko posebnog zakona, vlasnike obavežu na obaveznu popravku oštećenih i razrušenih zgrada. Finansijske nevolje, prema donetim propisima, vlasnike nisu oslobađale obaveze budući da su svi oni koji nisu raspolagali potrebnim novčanim sredstvima, bili dužni da preko odbora za obnovu zatraže zajam kako bi ispunili svoje zakonom utvrđene dužnosti. ${ }^{7}$ Tako je, što putem dobrovoljne, što putem prisilne obnove stambenih zgrada, samo u Beogradu do kraja 1947. bilo osposobljeno 2.000 stanova. ${ }^{8}$ Najnužnije opravke na zgradama su bile daleko od dovoljnih budući da je stambeni fond - usled starosti i višegodišnjeg neodržavanja, skupoće građevinskog materijala i građevinskih radova, nehata i nebrige useljenih stanara, preopterećenosti stanova i kirija nedovoljnih za pokrivanje osnovnih izdataka - bio u veoma lošem stanju. Polovina zgrada bila je podignuta pre 1919. godine, ${ }^{9}$ a o kvalitetu stanova i

\footnotetext{
${ }_{5}^{4}$ Predlog mera za rešavanje stambenog pitanja, AJ, 40-33-77.

${ }^{5}$ V. Yugoslavia in 1946 (Godišnji izveštaj ambasadora Čarlsa Pika), R. Jarman, Yugoslavia. Politicial Diaries 1918-1965, t III, London 1997, 743.

${ }_{7}^{6}$ Predlog mera za rešavanje stambenog pitanja, AJ, 40-33-77.

${ }^{7}$ Zakon o obaveznoj opravci oštećenih, raščišćavanju porušenih i dovršenju započetih stambenih zgrada na teritoriji Narodne Republike Srbije, Službeni glasnik Srbije, 30. mart 1946.

${ }^{8}$ Nezavedeno, bez datuma (verovatno iz 1948), I AB, 137-401.

${ }^{9}$ Pregled životnog standarda, A JBT, KPR III -A-1-b.
} 
životnim prilikama žitelja grada najupečatljivije je svedočila činjenica da je veliki broj zgrada samo „po nuždi bio nastanjen“, budući da se „u redovnim prilikama" u njima ne bi ni moglo živeti. ${ }^{10}$

U Prizrenu je čitava stambena četvrt bila sklona padu, ${ }^{11}$ a žalosne stambene prilike vladale su i u centralnim beogradskim opštinama. Tako su stanari Dobračine 35, jedne od centralnih prestoničkih ulica, bili prinuđeni da stanuju u zgradi na kojoj su svi prozori na stepeništu bili izlupani, sa jednim toaletom i jednom česmom koju je delilo 14 stanara! $^{12}$ U opštoj stambenoj oskudici, živelo se po leskovačkim „kafanama, šupama i podrumima", ${ }^{13} \mathrm{u}$ hodnicima i halama fabrike vagona $\mathrm{u}$ Kraljevu, ${ }^{14}$ kancelarijama državnih ustanova, ${ }^{15}$ vagonima, stovarištima uglja i drva, ${ }^{16}$ ali i sobici $u$ podzemnom javnom toaletu nedaleko od beogradskog Narodnog pozorišta. ${ }^{17}$ Štaviše, anketa sprovedena u prestonici 1955. godine je pokazala da je u opštini Stari Đeram bilo 63\%, a na Istočnom Vračaru 30\% nezdravih stanova. ${ }^{18}$ Najteže je ipak bilo u kosovsko-metohijskim gradovima gde su stanovi bili vlažni, mali, bez patosa i ikakvih uređaja. U čitavoj Prištini 1950. godine nije ni bilo pristojnih stanova, koji bi se prema tadašnjoj kategorizaciji mogli svrstati u I i II kategoriju. ${ }^{19}$ Uprkos stalnim konstatacijama vlasti o potrebi redovnog održavanja stambenog fonda i poboljšanja uslova života građana, situacija je do polovine pete decenije 20 . veka ostala nepromenjena, budući da je čak 35\% stanova u gradskim naseljima bilo oštećeno i dotrajalo. ${ }^{20}$

${ }^{10}$ Nezavedeno, bez datuma (verovatno iz 1948), I AB, 137-401. V. i Zapisnik sa sastanaka CK KP Srbije održanog 20. novembra 1947, AS, Đ2 - Politbiro (bez broja) - 1.

${ }^{11}$ Izveštaj sa obilaska Raške, Novog Pazara, Prizrena, Peći, Uroševca i Gnjilana, AS, G 125-68.

123039 od 11. marta 1948, I AB, 1.4.42 (Narodni odbor I reona grada Beograda) 88 (povereništvo za stanove).

${ }^{13}$ Br. 20059 od 27. avgusta 1950, AS, G 125-30. Slično je bilo i u Raškoj, gde su činovnici spavali „po kancelarijama na stolovima“; Izveštaj sa obilaska Raške, Novog Pazara, Prizrena, Peći, Uroševca i Gnjilana, AS, G 125-68.

${ }^{14}$ Godišnji izveštaj GK KPS Rankovićevo za 1949, AS, Đ 5-35.

${ }^{15}$ Godišnji izveštaj sreskog komiteta KPS za Ljig, AS, Đ4-1; Diskusija sekretara SK Ljig (ime nije navedeno). Stenografske beleške sa savetovanja CK sa sekretarima SK, rukovodiocima PK i OK održanog 9. i 10. februara 1949. godine, AS, Đ2-4- 3.

${ }_{16}$ Obalskim radnicima u Beogradu se moraju osigurati bolji životni uslovi, Borba, 25. mart 1948.

${ }^{17}$ Nezavedeno od 27. juna 1947, I AB, 1.4.42-90 (povereništvo za stanove).

${ }^{18}$ Stanovi, A JBT, KPR III - A - 1 - b.

${ }^{19}$ Predlog stambene izgradnje u Autonomnoj Kosovsko-metohijskoj oblasti u periodu 1953-1955, AS, G 125-68.

${ }^{20}$ Izlaganje S. Vukmanovića Tempa na Desetoj zajedničkoj sednici Saveznog veća i Veća proizvođača održanoj 27. decembra 1954. godine, Stenografske beleške Narodne skupštine za 1954, knjiga 2, Beograd 1955. 
Veliko siromaštvo, nemogućnost kupovine građevinskog materijala u slobodnoj prodaji, ali i stav vlasti, sve do početka 50-ih godina, da težnja za privatnom kućom ili stanom predstavlja izraz „sitnoburžoaskih stremljenja“, uticala je da u prvoj posleratnoj deceniji gotovo jedini graditelj novih stanova bude država. ${ }^{21}$ Vlasti su, svesne dramatičnosti stambene bede i njenih političkih i socijalnih implikacija, počev od 1949. godine pokušavale da nađu modalitet kojim bi na jevtin i brz način bio obezbeđen životni prostor većini stanovništva. I ovom prilikom se posegnulo za privremenim rešenjima, u skladu sa shvatanjem da se „stambene zgrade, građevinski materijal kao i delovi zgrada moraju tipizirati, standardizovati i proizvoditi industrijski“ ${ }^{22} \mathrm{U}$ vremenu velikih investicionih ulaganja, montažna gradnja se partijskom vrhu činila kao spasonosno rešenje. Osećaj za realnost je nestajao u velikim planovima, pa je polovinom 1949. godina na sednicama Privrednog saveta isticano da se od naredne godine mora pristupiti izgradnji montažnih delova za 100.000 stanova, za šta je bilo potrebno „postaviti“, čak „150 manjih fabrika, odnosno 75 većih“. Za ovaj poduhvat bilo je potrebno oko 80.000 radnika, ali su vlasti procenjivale da bi na montiranju kuća trebalo na dobrovoljnoj bazi" angažovati omladinu i radnike onih preduzeća čija će to kolonija biti. ${ }^{23}$ Iako su otpori prema montažnoj gradnji u Ministarstvu građevine i u drugim saveznim ministarstvima bili „strašni“, Privredni savet nije odustajao od zamisli da se gradnja ciglom u 1950. godini napusti, budući da je to bio jedini način za ostvarivanje preambiciozno postavljenog petogodišnjeg plana. ${ }^{24}$ Na Karaburmi, Mirijevskom i Lazarevačkom putu ${ }^{25}$ i na Voždovcu ${ }^{26}$ nicale su prve montažne zgrade, čudesno brz način gradnje popularisala je i štampa, ${ }^{27}$ a lokalni čelnici Valjeva su u obećanim objektima videli spasonosno rešenje stambenih neprilika. ${ }^{28}$ Međutim, uprkos poletu i početnom oduševljenju, najavljeni veliki rezultati su izostali.

Sa delimičnom demokratizacijom društva i labavljenjem čvrstih partijskih stega, lagano se menjao i odnos prema privatnom vlasništvu i indivi-

${ }^{21}$ Ekonomski problemi stambene izgradnje, A JBT, KPR III-A-4-x.

${ }^{22}$ Obrazloženje predloga plana za rešenje stambenog pitanja u FNRJ, AJ, 41-137-260.

${ }^{23}$ Zapisnik sa sastanka kolegijuma Savezne planske komisije po pitanjima druge polovine petogodišnjeg plana održanog 19. jula 1949, AJ, 40-4-9. V. i Zapisnik sa konferencije po pitanju dalje borbe za ispunjenje plana održane 13. jula 1949; AJ, 40-4-9.

${ }_{24}$ Zapisnik sa sednice po pitanju izgradnje tvornica za izradu delova montažnih kuća održane 10. septembra 1949. godine, AJ, 40-4-9.

${ }^{25}$ U gradu montažnih zgrada, Borba, 19. septembar 1950.

${ }^{26}$ Nezavedeno, bez datuma, AS, G 125-53.

${ }^{27}$ Ostvaruje se veliki plan izgradnje našeg glavnog grada, Borba, 21. juli 1949; Osam stanova za deset dana, Politika, 14. avgust 1948.

${ }^{28}$ Nezavedeno, bez datuma (iz 1949), MIAV, A 1. 5. 23-168. 
dualnoj gradnji. Donošenjem Uredbe o izgradnji stambenih zgrada u maju 1951. otvoren je put kreditiranju privatne gradnje. ${ }^{29}$ Zajmovi su se mogli podići na 30 godina sa kamatom 1-2\%, graditeljima je odobravana subvencija od $80 \%$ vrednosti ugrađenog materijala, a po potrebi im je dodeljivan i teren za gradnju. ${ }^{30}$ Kako bi se radnici na neki način vezali za preduzeća, a dnevne migracije svele na najmanju meru, predviđeno je da udaljenost zgrade od mesta zaposlenja ne bi trebalo da bude veća od 5 kilometara. ${ }^{31}$ Početno interesovanje bilo je veliko, a građani su uglavnom planirali gradnju prizemnih zgrada sa jednim stanom. ${ }^{32}$ Uprkos popularizaciji, montažna gradnja nije previše privlačila potencijalne graditelje, što zbog nepoverenja prema novom tipu objekata, što zbog činjenice da ovakve zgrade nisu bile ništa jevtinije od klasičnih. ${ }^{33}$ Svako ko je želeo da gradi, trebalo je da se prijavi lokalnom narodnom odboru koji je proveravao podatke i donosio rešenja po molbama. Međutim, sredstva dodeljena iz budžeta srpskim republičkim vlastima su bila skromna, a gradnju je otežavala i činjenica da su se male površine zemljišta nalazile $u$ državnim rukama. ${ }^{34}$ Teške ekonomske prilike i sveopšte siromaštvo uticalo je na građane da se teško odlučuju za uzimanje kredita, budući da se zbog prelaska na novi platni sistem strahovalo kako će se obračunavati zarade. ${ }^{35}$ Davanje kredita za individualnu izgradnju je dobilo na zamahu krajem 1952. godine, ali se ipak radilo o simboličnom broju odobrenih zahteva, više nego nedovoljnom da se na bilo koji način stambena situacija značajnije popravi. ${ }^{36}$

Iako su novine gotovo svakodnevno objavljivale napise o podizanju novih stambenih zgrada, izgradnja godišnjem nivou je, čak i prema zvaničnoj statistici, dosezala tek $70 \%$ predratne ${ }^{37} \mathrm{U}$ uslovima neprestanog mehaničkog priliva migranata $u$ gradove, stambena beda se iz godine u godinu povećavala, budući da tempo gradnje nije bio dovoljan čak ni da održi stam-

${ }^{29}$ Nezavedeno, bez datuma, AS, G 129-34.

${ }^{30}$ D. Stefanović, Stambena izgradnja i njeno finansiranje u gradovima FNRJ, Ekonomist, 1, 1955, 74 .

${ }^{31}$ Određivanje zemljišta za izgradnju stambenih zgrada radnika i službenika, AS, G 129-10.

32 Analiza ankete o izgradnji stambenih zgrada radnika i službenika (u smislu Uredbe Sl. list br 23 / 51), AS, G 129-51.

${ }^{33}$ Nezavedeno, bez datuma, AS, G 129-34.

${ }^{34}$ Zapisnik br. 21 sa sednica Privrednog saveta održane 14. avgusta 1951, AS, G 30 - nerazvrstano.

${ }^{35}$ Zapisnik br. 31 sa sednica Privrednog saveta održane 26. oktobra 1951, AS, G 30 - nerazvrstano.

${ }^{36}$ Prema jednom podatku, do kraja 1953. na teritoriji čitave Jugoslavije odobreno 9.317 kredita za individualnu izgradnju. - D. Stefanović, Stambena izgradnja i njeno finansiranje u gradovima FNRJ, Ekonomist, 1, 1955, 74.

${ }^{37}$ Stanovi, A JBT, KPR III-A-1-b. 
beni standard na istom nivou. Raspoloživa stambena površina po jednom stanovniku je bila u neprestanom opadanju, pa se u periodu 1950-1954. godine smanjila za $22 \%$, sa 11,6 metara kvadratnih na 8,7 metara kvadratnih. ${ }^{38}$ Situacija u gradovima širom Srbije je bila gotovo identična, a pred stambenim odsecima su stajale čitave kolone ljudi čekajući rešenje svog smeštaja. ${ }^{39}$ I pored politike „stešnjavanja“ u stanovima, mimo svih zakonskih propisa i potrebi domaćinstva ${ }^{40}$ rešenja problema jednostavno nije bilo. Stanovništvo Novog Sada, ${ }^{41}$ Smedereva, ${ }^{42}$ Leskovca, ${ }^{43}$ Šapca, Loznice, ${ }^{44}$ Valjeva ${ }^{45}$ Aranđelovca, ${ }^{46}$ Kragujevca ${ }^{47}$ Niša ${ }^{48}$ Sombora, Zrenjanina ${ }^{49}$ Ljiga $^{50}$ i mnogih drugih centara posle rata je naglo naraslo, a da u mnogim od navedenih gradova nije bio izgrađen gotovo nijedan novi stan. ${ }^{51} \mathrm{O}$ stepenu stambene bede rečito su svedočile i prilike u Obrenov$\mathrm{cu}$, varošici koja je sa predratnih 1.800 stanovnika do 1955. godine narasla na 8.000 . Kako su za čitavu deceniju posle oslobođenja podignute samo dve kuće, sekretar sreskog komiteta se na partijskom savetovanju jadao da u mestu „do pola noći spavaju jedni, a od pola noći spavaju drugi“ ${ }^{52}$ Najteže prilike su ipak vladale $u$ prestonici u kojoj se stambena kriza iz godine u godinu zaoštravala „i to sa kumulativnim efektom“, ${ }^{53}$ budući da je u prvoj posleratnoj deceniji podignuto svega 16.540 novih

${ }^{38}$ Pregled životnog standarda (28. novembar 1956), A JBT, III-a-1-b.

${ }^{39}$ Izveštaj GK KPS za Kragujevac za 1949. godinu, AS, Đ 5-13.

${ }^{40}$ Izveštaj GK KPS za Kragujevac za 1949, AS, Đ5-13; Stambena situacija u Šapcu i

Valjevu, AS, G 125-68; Nezavedeno, bez datuma (iz 1952), MIAV, A 1. 5. 23-191.

${ }^{41}$ Godišnji izveštaj Pokrajinskog komiteta KPS za Vojvodinu (1949. godina), AV, 334-1042.

${ }^{42}$ Izveštaj ekipe CK KPS o radu gradskog komiteta Smederevo, AS, Đ 4-30.

${ }^{43} \mathrm{Br} .20 .059$ od 27. avgusta 1950, AS, G 125-30.

${ }^{44}$ Godišnji izveštaj o radu sreskog komiteta KPS za srez Jadarski za 1950. godinu,

AS, Đ 4-4; Nepravilni postupci oficira i boraca J. A. na terenu našeg sreza, AS, Đ 4-1.

${ }^{45}$ Nezavedeno, bez datuma (iz 1949), MIAV, A 1. 5. 23-168.

${ }^{46}$ Godišnji izveštaj o radu sreskog komiteta KPS za srez Orašački u Aranđelovcu za 1950. godinu, AS, Đ 5-13.

${ }^{47}$ Izveštaj GK KPS za Kragujevac za 1949, AS, Đ5-13.

${ }^{48}$ Godišnji izveštaj za 1949. godinu o radu partijskih organa grada Niša, AS, Đ6-3.

${ }^{49}$ Godišnji izveštaj Pokrajinskog komiteta KPS za Vojvodinu (1947. godina), AV-334-1041; Godišnji izveštaj Pokrajinskog komiteta KPS za Vojvodinu (1949. godina), AV-334-1041.

${ }^{50}$ Diskusija sekretara SK Ljig (ime nije navedeno). Stenografske beleške sa savetovanja CK sa sekretarima SK, rukovodiocima PK i OK održanog 9. i 10. februara 1949. godine, AS, Đ2-4-3.

${ }^{51}$ Prema zvaničnoj statistici, u periodu od oslobođenja do kraja 1947. godine na teritoriji Srbije je bilo sagrađeno svega 188 stambenih zgrada; Pov. Broj 2322 od 8. jula 1948, AJ, 13-99; Analiza komunalne problematike na teritoriji APV, AS, G 129-13.

\footnotetext{
${ }^{52}$ Savetovanja sa sekretarima sreskih komiteta, 5-6. oktobra 1955, AS, Đ 2-4-2.

${ }^{53}$ Beograd, AJ, 130-749-1210.
} 
stanova. ${ }^{54}$ Pokušaji da se ograniči mehanički priliv stanovništva u prestonicu, za koje su se gradske vlasti zalagale i 1951. godine, nisu davali gotovo nikakve rezultate. ${ }^{55}$ Stoga je 1953. godine na jednog Beograđanina dolazilo 9,9 kvadratnih metara stambene površine, što je bilo daleko ispod evropskih standarda koji su iznosili između 15 i 23 kvadratna metra, ali i prilika u Ljubljani $(14,4)$, Zagrebu $(12,4)$, pa čak i Sarajevu $(10,7){ }^{56}$ Težine životnih prilika i eventualnih političkih posledica nerešavanja zaoštrenog stambenog pitanja su bile svesne i državne vlasti. Konstatovano je da životne prilike ugrožavaju ne samo komociju stanara i njihovo pravo na privatnost, već da se najdirektnije odražavaju na zdravlje ljudi, „njihov moral i radnu sposobnost". 57

Stambenu oskudicu je dodatno povećavala praksa po kojoj su državna nadleštva i socijalistička preduzeća, ${ }^{58}$ ali i vojna lica, u nedostatku adekvatnog poslovnog prostora i administrativnih zgrada, useljavana u prethodno oduzete kuće i stanove. ${ }^{59}$ U uslovima stalne stambene bede, posebno bahato su se ponašali nekadašnji oslobodioci, mahom oficiri, koji nisu prezali ni od nasilnog useljavanja u stanove, niti od njihovog ruiniranja. U Loznici se nisu zadovoljavali bilo kakvim smeštajem, već samo „reprezentativnim" stanovima kojih u gradu nije bilo, dok su vojnici koji su stanovali u vilama Banje Koviljače iza sebe ostavili pravu pustoš - porazbijane prozore, polomljene brave i „zapuštene električne instalacije“.${ }^{60} \mathrm{U}$ velikim problemima su se našle i lokalne vlasti, pokušavajući da reše nerešivo, pa se $u$ Jagodini razmišljalo čak i o iseljavanju penzionera „koji nisu svojim potrebama vezani za grad" u obližnja sela. ${ }^{61}$

Republičke razlike bile su minimalne, pa je čak i u Ljubljani, koja je imala „najrazvijeniju stambenu površinu“, postojao veliki manjak stanova. ${ }^{62}$ O dramatičnosti razmera stambene krize rečito je govorila procena vlasti,

${ }^{54}$ B. Furundžić, Građevinska delatnost Beograda u periodu 1944-1964, Godišnjak grada Beograda, 1-2, 1964, 103.

${ }^{55}$ Stenografske beleške sa IV gradske posleratne konferencije održane $3-4$. februara 1951, A IB, 137-145.

${ }^{56}$ Beograd, AJ, 130-749-1210. V. i Lj. Blagojević, Novi Beograd - osporeni modernizam, Beograd 2007, 135. O razmerama stambene bede svedoči i podatak da je 1950. godine na jednu sobu u SAD dolazilo 0,75 stanovnika, u Zapadnoj Evropi 1,1, u Istočnoj Evropi 1,9, dok je u FNRJ u proseku jednu sobu delilo 2,35 osoba!; M. C. Kaser, E. A. Radice, The Economic History of Eastern Europe, 1919-1975, t III, Oxford 1986, 343.

${ }^{57}$ Beograd, AJ, 130-749-1210.

${ }^{58}$ Izveštaj o delatnosti Ministarstva komunalnih poslova za AP Vojvodinu za 1948, AS, G 125-57; Izveštaj GK KPS za Kragujevac za 1949. godinu, AS, Đ 5-13.

${ }^{59}$ Nepravilni postupci oficira i boraca J. A. na terenu našeg sreza, AS, Đ 4-1; Izveštaj sa obilaska Raške, Novog Pazara, Prizrena, Peći, Uroševca i Gnjilana, AS, G 125-68.

${ }^{60}$ Nepravilni postupci oficira i boraca J. A. na terenu našeg sreza, AS, Đ 4-1.

${ }^{61}$ Marković Stanimir - izveštaj sa terena (GNO Svetozarevo), AS, G 125-68.

${ }^{62}$ Nezavedeno, A JBT, KPR III-A-1-b. 
sačinjena 1955. godine, po kojoj bi „za jedan podnošljiv, ali ne i zadovoljavajući standard" u čitavoj Jugoslaviji trebalo podići 200.000 novih stanova u gradu i još 800.000 na selu! Stambenu oskudicu nije bilo moguće prikriti, pa se krajem 1955. godine u Borbi moglo pročitati da je u Nišu na jednog stanovnika dolazilo 8,8 kvadratnih metara stambene površine, u Kruševcu 6,1, u Vukovaru 10, Sisku 7, Kranju 11,8, Celju 10, Štipu 7,2 što je bilo ispod "naučno utvrđenog minimuma“. ${ }^{63}$ Jugoslavija se tako, po nivou stanovanja, nalazila na samom evropskom dnu, ostavljajući iza sebe još jedino Grčku. ${ }^{64} \mathrm{U}$ datim okolnostima, optimizam je napuštao i poslovično optimističnu jugoslovensku štampu, pa je NIN „prognozirao“ da bi tri miliona novih stanova rešilo stambenu krizu, ali tek 1980. godine! ${ }^{65}$

Paradoksalno, novoizgrađeni stanovi ne samo po broju, već i po strukturi nisu doprinosili rešenju stambene bede. Iako se maštalo o „fabrikama za stanovanje i kolektivima stanara“" ${ }^{66}$ po rubovima gradova nicala su nova naselja, obično bez struje, vode, prosečenih ulica i najnužnije infrastrukture. Težnja da se površina što više smanji, kratki rokovi projektovanja i neiskustvo projektanata uticali su da stanovi, čak i oni prestonički, budu neudobni i nekomforni. Izbor lokacije je vršen nasumično, gradovi su rasli $\mathrm{u}$ širinu više nego što je bilo nužno ${ }^{67}$ a nikakva pažnja nije pridavana ni orijentaciji zgrada s obzirom na strane sveta i pravac najjačih vetrova ${ }^{68}$ Arhitekte su uzaludno upozoravale da su nova naselja „svedena i ružna“, posebno kritikujući odsustvo makar i minimalnog truda kojim bi se izgrađeni objekti koliko-toliko arhitektonski uklopili u okolinu. ${ }^{69}$ Širom zemlje nicale su mračne zgrade malih ulaza, nedovoljno izolovane od vlage i promaje, bez osnovnih sanitarnih uređaja i sa privremenim dvorišnim toaletima. ${ }^{70}$ Kao po nekom nepisanom pravilu, u toku gradnju nestajalo je novca, pa su stanari useljavani u nedovršene objekte koji su stajali na sred praznog i neure-

${ }^{63}$ Naš stambeni minimum, Borba, 7. decembar 1955.

${ }^{64}$ Problemi životnog standarda (9. juni 1955), A JBT, KPR III-A-1-b; Izlaganje Kire Gligorova. Zapisnik sa sastanka odbora za privredu održanog 8. aprila 1955, AJ, 130-8301308.

${ }^{65}$ Jedna zanimljiva prognoza o našoj stambenoj budućnosti. Tri miliona stanova rešilo bi stambenu krizu, NIN, 13. mart 1955. V. Kako obezbediti sredstva za stambenu izgradnju, NIN, 28. mart 1954.

${ }^{66}$ Savetovanje arhitekata i urbanista u Dubrovniku 1950, Arhitektura, 11-12, 1950, 16.

${ }^{67}$ M. Živković, S. Bakić, Beograd. Sociološka studija, Beograd 1977, 187.

${ }^{68}$ Izveštaj o stanovima i stambenim zgradama podignutim u Beogradu u vremenu 1947-1951, AS, G 125-53.

${ }^{69}$ Savetovanje arhitekata i urbanista u Dubrovniku 1950, Arhitektura, 11-12, 1950, 25.

${ }^{70}$ Izveštaj o stanovima i stambenim zgradama podignutim u Beogradu u vremenu 1947-1951, AS, G 125-53; Godišnji izveštaj Sreskog komiteta KPS sreza smederevskog (1949), AS, Đ4-1; Izveštaj sa službenog putovanja po NR Srbiji radi obilaska novih naselja; AJ, 31-28-46; Izveštaj gradskog odbora AFŽ Niš, AJ, 141-13-70. 
đenog terena, kilometrima daleko od ulica, gradskog saobraćaja, prodavnica, fabrika i škola. ${ }^{71}$ Ova žalosna praksa je bila posebno izražena u velikim gradovima. Tako su stanovnici beogradskih naselja - Tošinog bunara $^{72}$ Karaburme, ${ }^{73}$ Železnika ${ }^{74}$ i Rakovice useljavani u stanove bez vodovodnih i električnih instalacija, parketa ${ }^{75}$ ali i bilo kakvog grejanja. ${ }^{76}$ Nemar građevinskih preduzeća kao da nije imao granice, pa je odsustvo zaštitne ograde na terasama jedne zgrade u Beogradu pravdano „štednjom “. ${ }^{77}$ Uprkos preziru prema intelektualcima i platnoj politici koja je favorizovala manuelni rad, pri dodeli stanova stvari su stajale drugačije. U opštoj oskudici, bilo je gotovo nemoguće „obične radnike iz podruma izvaditi“. Preduzećima su bili potrebni malobrojni inženjeri i stručni tehničari koji su, kao uslov zaposlenja, po pravilu zahtevali rešenje stambenog pitanja. ${ }^{78}$ Štaviše, i dobijanje stana radnicima ništa nije garantovalo, budući da su i one fabrike koje su izgradile samačke stanove bile sklone da iz njih iseljavaju radnike i vraćaju ih u provizorne barake, kako bi obezbedili prostor za stručnjake ili ga jednostavno koristili za druge potrebe. ${ }^{79}$

Usled velike stambene bede, stanovnici gradova su u prvim posleratnim godinama živeli u neprestanom stanju nesigurnosti i straha, ${ }^{80}$ budući da je svakog trenutka mogla stići naredba o deložaciji ili pak neželjeni sustanar. I sami državni organi su priznavali da je intervencija, ${ }^{81}$ nezakonitih postupaka i nepravilnosti u dodeljivanju stanova bilo na pretek, a dešavalo se i da se, u cilju rešavanja problema građana bez stana, „prave najrazličitije kombinacije ${ }^{\text {«82 }}$ i stvara potpun haos lančanim pomeranjem $4-5$

${ }^{71}$ V. i M. Bobić, S. Vujović, Krov nad glavom. Ogledi o stambenoj bedi i siromaštvu, Beograd 1985, 161.

${ }_{72}^{7 z}$ Izeštaj o stanju i problemima građenja Novog Beograda, A JBT, KPR III-A-4-X.

${ }^{73}$ Nove zgrade nad kućercima, Borba, 3. maj 1951.

${ }^{74}$ Radmila Radić navodi da je deo novopodignutih zgrada u Železniku bio ostavljen bez slavina, pa se voda u stanovima točila direktno iz cevi; R. Radić, Pitanje socijalno-zdravstvene situacije u FNRJ 1948-1952, Tokovi revolucije, 1, 1989, 221.

${ }^{75}$ Nezavedeno, bez datuma, AS, G 125-53.

${ }^{76}$ Ko vodi brigu o radničkom naselju na Mirijevskom putu, „20. oktobar“, 14. januar 1949.

${ }^{77}$ Nezavedeno, bez datuma (verovatno iz 1951), AS, G 125-53.

${ }^{78}$ Zapisnik sa sastanka komisije za plaće i životni standard pri Republičkom odboru metalskih radnika Hrvatske, održanog dne 18. X. 1956. u Zagrebu, A JBT, KPR III-A-1-b.

${ }^{79}$ Referat o problemima radničke omladine, AJ, 114-93.

${ }^{80} \mathrm{~V}$. Stenografske beleške sa IV gradske posleratne konferencije održane 3-4. februara 1951, A IB, 136-145; Izveštaj GK KPs za Kragujevac za 1950, AS, Đ 5-13.

${ }^{81}$ Analiza komunalne problematike na teritoriji APV, AS, G 129-13; Izveštaj Slobodana Stanojevića o izvršenom službenom putovanju do Kragujevca, Vrnjačke Banje, Trstenika i Kruševca u novembru 1950, AS, G 125-68, Problemi u vezi sa distribucijom stanova, AS, G 129-3.

${ }^{82}$ Stenografske beleške sa IV gradske posleratne konferencije održane 3-4. februara 1951, A IB, 136-145. 
porodica iz jednog stana $\mathrm{u}$ drugi. ${ }^{83} \mathrm{U}$ Pančevu je, tako, iz vlastitog stana $\mathrm{u}$ drugi iste veličine preseljen „neki Nemac" „samo zato što ima stan u svojoj kući“. ${ }^{84}$ Nasilno oduzimanje stanova ${ }^{85}$ i drugi nezakoniti postupci, improvizacije, nepotrebna preseljenja ili izdavanje više rešenja za isti stan, uticala su na političko raspoloženje stanovništva. ${ }^{86}$ Iako je bilo predviđeno da prvenstvo u dodeljivanju stanova imaju porodice sa malom decom, bolesna lica ${ }^{87}$ ili pak radnici, ${ }^{88}$ u praksi je bilo drugačije. Vladajuća elita u nastajanju brzo je zaboravljala na sopstvena uverenja o socijalnoj pravdi, birajući za sebe najbolje i najluksuznije stanove. ${ }^{89}$ Pri sveopštoj oskudici stambenog prostora, u gradovima je često važio zakon jačeg i uticajnijeg, pa se dešavalo da se građani „ubacuju u stan bez rešenja“, posle čega je, naknadnim izdavanjem dozvole, njihov položaj u „zauzetom“ stanu bio i legalizovan. ${ }^{90}$ Gotovo po pravilu, rešavanje jednog stambenog problema prouzrokovalo je novu nepravdu, a iz stanova je najlakše bilo iseliti učitelje i profesore kako bi se u njih useli „zaslužniji“ građani, mahom oficiri i lokalni partijski funkcioneri. ${ }^{91}$ „Drugovima u stambenom odseku vrlo teško“, čulo se na plenumu SK Pančeva „jer im svi organi vlasti naređuju - i Komanda divizije, Javno tužilaštvo, Savet unutrašnjih poslova". ${ }^{92}$ Nerešene molbe u beogradskom povereništvu za stanove su stajale i po pet godina, ${ }^{93}$ a pri donošenju rešenja za useljenje ili iseljenje retki su bili slučajevi da stanar kome je bilo naloženo da se seli ne uloži žalbu. ${ }^{94}$ Kako su u nekim slučajevima deložacije vrše-

${ }^{83}$ Marković Stanimir - izveštaj sa terena (GNO Ćuprija), AS, G 125-68; Analiza komunalne problematike na teritoriji APV, AS, G 129-13. Nezavedeno, bez datuma (iz 1949), MIAV, A 1. 5. 23-168.

${ }^{84}$ Zapisnik sa savetovanja proširenog Plenuma SK KPS Pančevo održanog na dan 2. juna 1952, IAP, 319-66.

${ }^{85}$ Zapisnik sa sastanka CK KPS održanog u utorak, 16. novembra 1948, AS, Đ2 Politbiro (bez broja) - novooformljena kutija (bez broja).

${ }^{86}$ Izveštaj GK KPS za Kragujevac za 1950, AS, Đ5-13.

${ }^{87}$ Izveštaj Slobodana Stanojevića o izvršenom službenom putovanju do Kragujevca, Vrnjačke Banje, Trstenika i Kruševca u novembru 1950, AS, G 125-68.

${ }^{88}$ Analiza komunalne problematike na teritoriji APV, AS, G 129-13.

${ }^{89}$ Zapažanja o radu partijskih organizacija u Vojvodini, AS, Đ2-10 (Odeljenje za informacije) - 1, Rad na donošenju regulativnih propisa, mera na primeni pravnih propisa iz oblasti stambeno-komunalne delatnosti, AS, G 129-9.

${ }^{90}$ Analiza komunalne problematike na teritoriji APV, AS, G 129-13; Čistoća i komunalne usluge, AS, G 129-13; Izveštaj o komunalnim problemima na Kosovu i Metohiji, AS, G 129-13; Nezavedeno, bez datuma (iz 1949), MIAV, A 1. 5. 23-168.

${ }^{91}$ Primeri nepravilnog odnosa prema prosvetnim radnicima (korišćenje van škola i ustanova, materijalni položaj), AS, Đ2-9-3.

${ }_{92}$ Zapisnik sa savetovanja proširenog Plenuma SK KPS Pančevo održanog na dan 2. juna 1952, IAP, 319-66.

${ }_{93}$ Da li se molbe za stanove mogu brže rešavati?, Borba, 22. januar 1952.

${ }^{94}$ Izveštaj Slobodana Stanojevića o izvršenom službenom putovanju do Kragujevca, Vrnjačke Banje, Trstenika i Kruševca u novembru 1950, AS, G 125-68. 
ne i pre pravosnažnosti odluke, ${ }^{95}$ gnevni građani su žalbe upućivali ne samo lokalnim stambenim komisijama već i Predsedništvu vlade, Kontrolnoj komisiji, Javnom tužilaštvu, pa čak i Josipu Brozu lično. Greške i propuste stambenih organa nije bilo lako ispraviti - u Nišu su tokom 1949. godine četiri puta menjani upravnici Stambenog odseka, ali se situacija nije ni malo popravila. ${ }^{96}$

U situaciji u kojoj se stambeno pitanje pretvaralo u „važno političko pitanje“ ${ }^{97}$ jedino partijsko „rešenje“ za izlaz iz stambene krize predstavljala je institucija „zajedničkog stana“. Deljenje stanova, naročito po velikim gradovima, bilo je do te mere rasprostranjeno da su vlasti polovinom pedesetih godina procenjivale da u preko 30\% svih stanova živi dva ili više domaćinstava. ${ }^{98}$ Pravo privatnog vlasništva nije previše uvažavano, pa se dešavalo da se čitave porodice iseljavaju iz svojih domova i prebacuju u neki drugi stan. ${ }^{99}$ Iz vizure čelnika stambenih odbora bitno je bilo samo jedno - politikom „stešnjavanja“ rešiti što veći broj molbi. U takvim okolnostima nije se vodilo računa ni o broju članova domaćinstva, njihovom uzrastu ili potrebama, pa je stan od mesta rezervisanog za odmor i mir postajao poprište sukoba sustanara. ${ }^{100}$ Trudeći se da zadrže koliko-toliko pristojne uslove stanovanja, građani su se snalazili kako su znali i umeli, useljavajući, često i fiktivno, svoje rođake ili prijatelje u slobodne sobe. ${ }^{101}$ Opšta stambena oskudica i atmosfera nadzora svih nad svima uticale su da denuncijacije i „referisanje" o slobodnim stanovima u koje bi se moglo useliti postanu masovni. ${ }^{102}$

${ }^{95}$ Analiza komunalne problematike na teritoriji APV, AS, G 129-13.

${ }^{96}$ Godišnji izveštaj za 1949. godinu o radu partijskih organa grada Niša, AS, Đ6-3.

${ }^{97}$ Stenografske beleške sa VI gradske konferencije SK Beograda 7-8. oktobra 1955, I AB, 136-151; Zapisnik sa savetovanja proširenog Plenuma SK KPS Pančevo održanog na dan 2. juna 1952, IAP, 319-66.

${ }^{98}$ Pregled životnog standarda - nacrt, A JBT, KPR III-A-1-b. Štaviše, u nekim mestima se ovaj procenat peo i na 50\%, Izlaganje S. Vukmanovića - Tempa na Desetoj zajedničkoj sednici Saveznog veća i Veća proizvođača održanoj 27. decembra 1954. godine, Stenografske beleške Narodne skupštine za 1954, knjiga 2, Beograd 1955.

${ }_{99}$ Rad na donošenju regulativnih pravnih propisa iz oblasti stambeno-komunalne delatnosti, AS, G 129-9; Žalba inžinjera Živojina Kovačevića od 9. avgusta 1947, I AB, 1. 4. 42-88.

${ }^{100}$ Zapisnik sa VII sednice NO opštine Valjevo održane na dan 26. 11. 1955, MIAV, A 1. 5. 23-86.

${ }^{101}$ Ne koristi se dovoljno odluka o sporazumnom useljavanju u nastanjene stanove, „20. oktobar“, 26. juli 1946; Izveštaj Slobodana Stanojevića o izvršenom službenom putovanju do Kragujevca, Vrnjačke Banje, Trstenika i Kruševca u novembru 1950, AS, G 125-68.

102 Izveštaj Slobodana Stanojevića o izvršenom službenom putovanju do Kragujevca, Vrnjačke Banje, Trstenika i Kruševca (novembar 1950), AS, G 125-68; Zapisnik sa sastanka predsedništva Mesnog sindikalnog veća i rukovodilaca odeljenja sindikata održan 7. maja 1949, AS, Đ 2-16-7. 
Partijski čelnici su javno, preko novina, pozivali stanovništvo da prijavljuju svoje susede za koje procene da imaju višak stambenog prostora, ${ }^{103}$ pa je briga o „pravilnom" korišćenju stanova proglašena obavezom i „dužnošću“ svakog građanina. ${ }^{104}$ Posebna „odgovornost“ je pripala članovima Narodnog fronta čiji je zadatak bio da se „masovno angažuju u pronalaženju dovoljno neiskorišćenog stambenog prostora“, ali i da otkrivaju sve one koji „po svim propisima i pravu ne bi trebalo da žive u Beogradu i da zauzimaju mesto našim oficirima, radnicima i službenicima“. ${ }^{105}$ Kampanja za otkrivanje stambenog viška poprimila je oblike prave hajke u kojoj je štampa objavljivala imena i adrese ljudi, koji su, prema partijskim merilima, „neracionalno koristili“" svoje stanove. ${ }^{106}$ Dešavalo se tako da se isti stanovi, na osnovi prijave, proveravaju i više puta nedeljno, ali i da se bez krova nad glavom ostavljaju stara i bolesna lica koja iz svog doma nisu imala kud, osim na ulicu. ${ }^{107}$ Novo socijalističko društvo u izgradnji oduzimalo je građanima pravo na privatnost, a porodične i bračne prilike i imovinsko stanje su iz domena intime na najokrutniji i najdrastičniji način prelazile $u$ domen javnog i postajale predmet razmatranja stambenih odseka, štampe ali i svih onih koji su, kako bi popravili sopstvene životne prilike, reflektovali na jedan, sasvim određen stan. Bilo je naravno i izuzetaka - u partijskoj, „idealno pravednoj" državi zaštićeni su bili jedino rukovodioci čija veličina i iskorišćenost stana nije smela biti dovedena u pitanje. ${ }^{108}$

Mada je zakon o raspolaganju stanovima jasno propisivao da se od stana mogu uzimati samo sobe, a ne i pomoćne prostorije, ljudi su se često useljavali u tuđa predsoblja vešernice, ostave i biblioteke. ${ }^{109} \mathrm{Na}$ jednu sobu u gradovima je dolazilo po 2,23 lica, ${ }^{110}$ pa je u trosobnim stanovima u Beogradu neretko stanovalo i po 7-8 ljudi. ${ }^{111} \mathrm{U}$ prenaseljenim stanovima o kvalitetnom životu nije bilo ni govora, a i onako skučen prostor koji je stajao na raspolaganju jednoj porodici je u stvarnosti bio još manji, budući da su sobe više ličile na magacine sa nameštajem nego na mesto odmora i relak-

${ }^{103}$ Treba ukazivati na neiskorišćene stanove, „20. oktobar“, 17. juni 1949.

${ }^{104}$ Pitanja koja najčešće dolaze pred stambene organe, Politika, 2. april 1951.

${ }^{105}$ Referat Rata Dugonjića, Stenografske beleške sa konferencije Glavnog odbora Narodnog fronta održane 23. 9. 1948, AS, Đ 75-47.

${ }^{106}$ Okružnica Centralnog odbora jedinstvenih sindikata o stambenom pitanju, Borba,

22. februar 1947; Zbor birača u Trećem reonu traži da se popravljaju zgrade i pravilnije iskorišćavaju stanovi, Politika, 7. januar 1951.

${ }^{107} \mathrm{Rad}$ na donošenju regulativnih pravnih propisa iz oblasti stambeno-komunalne delatnosti, AS, G 129-9.

${ }_{108}$ I AB, 1. 4. 42-96. (povereništvo za stanove).

${ }^{109}$ V. AS, G 129-1.

${ }^{110}$ Problemi životnog standarda (9. juni 1955), A JBT, KPR III-A-1-b.

${ }^{111}$ Izveštaj o izvršenoj proveri zgrade u ulici Obilićev venac br. 23-25, IAB-1. 4. 42-98 (povereništvo za stanove). 
sacije. ${ }^{112}$ Nestajale su i brojne zajedničke prostorije - vešernice, tavani, podrumi i ostave, ${ }^{113}$ a zajedničko stanovanje je donosilo gubitak prava na privatnost i intimu, budući da su različite porodice, na putu do kuhinje ili kupatila, morale prolaziti jedna drugoj kroz spavaće sobe! ${ }^{114}$ Život potpunih stanaca na malom prostoru, uz zajedničku upotrebu "sporednih" prostorija, proticao je atmosferi stalnih čarki i sukoba, najčešće oko zajedničkih prostorija, a građani nezadovoljni odnosom sa sustanarima neprestano su se obraćali državnim organima, pa čak i Javnom tužilaštvu, za intervenciju. ${ }^{115}$ Osim privatnosti, u zajedničkom stanu su bili ugroženi mentalno zdravlje, ${ }^{116}$ ali i porodični odnosi, ${ }^{117}$ pa je procenjivano da je veliki broj razvoda prouzrokovan upravo stambenim neprilikama. ${ }^{118}$ Paradoksalno, stambena politika vlasti nije značila samo snižavanje kvaliteta života i gubitak privatnosti žitelja zajedničkih stanova, već je direktno prouzrokovala uništavanje i ruiniranje ionako malobrojnih zgrada. Porodice stešnjene u malim sobama, u kojima jedva da je bilo mesta i za stvari a kamo li za normalan život, nisu imale ni želje, ni volje, a ni interesa da u stalnoj atmosferi privremenosti i iščekivanja preseljenja redovno održavaju prostorije koje su im dati na korišćenje.

U prvoj posleratnoj deceniji vlasti ne samo da nisu bile kadre da izgradnjom koliko-toliko osiguraju pristojan život građana, već su politikom „stešnjavanja“ i niskim kirijama koje su predstavljale socijalnu, a ne ekonomsku kategoriju, doprinosile rapidnom ruiniranju i upropašćavanju i postojećeg stambenog fonda. Kako su rente sa svega $4-5 \%$ učestvovale $u$ ukupnim troškovima života, stanodavci nisu imali ni mogućnosti, a ni interesa da stambene zgrade redovno održavaju i popravljaju. Da bi platio mesečnu zakupninu jednosobnog stana, radnik je prema zvaničnim statističkim podacima iz 1955. godine, koje u razmatranom periodu uvek treba uzimati sa rezervom, morao da radi samo 12 sati, koliko vremena mu je trebalo i da bi zaradio za 2 kilograma svinjskog mesa! ${ }^{119}$ Iako je krivica za

${ }^{112}$ Br. 10949 od 11. novembra 1947, AS, G 125-1.

${ }^{113}$ O čuvanju postojećeg stambenog fonda, AS, G 129-29.

114 Žalba Save Mašića, IAGB, 1. 4. 42- 98 (povereništvo za stanove).

${ }^{115}$ V. I AB, 1. 4. 42, fascikle 87, 88 i 89. Kao najčešće razloge pritužbi na sustanare, Stambeni odsek beogradskog I reona je navodio: sporove oko zajedničkih prostorija, korišćenje peći u kuhinji, nepravilnu upotrebe sanitarija, primanja gostiju, stalan plač dece, dovođenje društva, upotrebu podruma, ljubomoru i međusobnu netrpeljivost; I AB, 1. 4. 42-91.

${ }^{116}$ S. Vujović, Stambene kriza i ljudske potrebe, Sociologija, 4, 1979, 447.

${ }^{117}$ R. Vujnović, O kompleksnoj stambenoj izgradnji, Stan i stanovanje, Beograd, bez godine izdanja, 11.

${ }_{118}$ Zašto se razvode brakovi u Beogradu, NIN, 5. avgust 1951; Zašto se razvode brakovi, NIN, 18. decembar 1955.

${ }^{119}$ I. Dobrivojević, Život u socijalizmu. Prilog proučavanju životnog standarda građana u FNRJ 1945-1955, Istorija 20. veka, 1, 2009, 82; Problemi životnog standarda, A JBT, KPR III-A-1-b. 
devastiranje stambenog fonda mahom prebacivana na prema novom poretku neraspoložene bivše rentijere, situacija je bila daleko složenija. Ni same vlasti u početku nisu uviđale neophodnost redovnog održavanja stambenog fonda, pa do 1949. godine nikakva sredstva nisu ni planirana za izvođenje nužnih popravki na zgradama. ${ }^{120} \mathrm{U}$ ovakvim okolnostima, posebno teške prilike su vladale u Vojvodini, s obzirom na to da je veliki deo zgrada bio od lošeg materijala - čerpiča i naboja, pa su se usled neodržavanja, nebrige stanara i slabog upravljanja državnim zgradama "gotove zgrade rušile“. ${ }^{121}$ Iako su na teritoriji uže Srbije prilike bile za nijansu povoljnije, bilo je neophodno sanirati veliki deo građevina u Leskovcu, Kragujevcu, Nišu, Smederevu, Kragujevcu i Kraljevu u kojima su posledice rata i bile najveće. ${ }^{122}$ Slično je bilo i u prestonici gde je zbog dotrajalih, zapuštenih i neispravnih instalacija gotovo po pravilu dolazilo do „vlaženja zidova, opadanja plafona i nepotrebnog izlivanja vode." Dodatnom ruiniranju su doprinosile i same vlasti koje su i ono malo raspoloživih sredstava predviđenih za popravke trošili na sređivanje fasada, dok su krovovi i oluci, usled nedostatka lima, ostajali nesanirani. ${ }^{123}$

U potpunosti svesne težine stambenog problema i njegovih potencijalnih političkih implikacija, ${ }^{124}$ vlasti su iz godine u godinu najavljivale povećanje ulaganja u standard, a samim tim i u stanogradnju. ${ }^{125}$ Veliki planovi najčešće nisu imali mnogo veze sa stvarnim državnim mogućnostima, pa je u periodu 1951-1956. godine, u skladu sa zamislima partijskih funkcionera, trebalo podići samo u Beogradu čak 50.000 novih stanova! ${ }^{126}$ Međutim, jasno definisani ekonomski prioriteti, neprestana gradnja kapitalnih objekata kojoj se nije nazirao kraj ni 1954. godine, ali i teška finansijska kriza prouzrokovana prekomernim investiranjem i zaduživanje, uticali su da izgradnja novih stambenih zgrada, sve do kraja razmatranog perioda bude više nego nedovoljna. ${ }^{127}$ Sredinom 1955. godine i vlastima je postalo jasno da se dotadašnjim putem u stambenoj politici više ne može ići budući da je krizu bilo „nemoguće rešiti bez individualne svojine stanova“, odno-

${ }^{120}$ Održavanje zgrada, AS, G 129-20.

${ }_{121}$ Analiza komunalne problematike na teritoriji APV, AS, G 129-13.

122 Održavanje zgrada, AS, G 129-20.

${ }^{123}$ Stanje održavanja stambenog fonda, I AB, 136-401.

124 Stenografske beleške sa VI gradske konferencije SK Beograda održane 7-8. oktobra 1955, I AB, 136-151.

${ }^{125}$ V. Izlaganje S. Vukmanovića - Tempa na Desetoj zajedničkoj sednici Saveznog veća i Veća proizvođača održanoj 27. decembra 1954. godine, Stenografske beleške Narodne skupštine za 1954, knjiga 2, Beograd 1955.

${ }^{126}$ Zabeleška sa sastanka održanog 5. jula 1950. godine kod druga Đilasa po pitanju izgradnje Beograda u godinama 1951-56, AJ, 40-5-10.

${ }^{127}$ V. B. Furundžić, Građevinska delatnost Beograda u periodu 1944-1964, Godišnjak grada Beograda, 1-2, 1964, 103. 
sno „bez ulaganja znatnog dela nadnica radnika i službenika za izgradnju stanova“. ${ }^{128}$ Stoga je na samom izmaku godine uveden doprinos od $10 \%$ za stambenu izgradnju koji su bili obavezne da plaćaju „privredne organizacije, ustanove, državni organi, društvene i zadružne organizacije kao i druge osobe koje zapošljavaju tuđu radnu snagu“" ${ }^{129}$ Međutim, i pored izvesnih promena u stambenoj politici, Jugoslavija je, i polovinom šezdesetih godina, bila na samom dnu evropske lestvice po broju izgrađenih stanova na 1.000 stanovnika, ${ }^{130}$ a izlaz iz stambene bede "nađen“ je u divljoj gradnji, čiji su glavni nosioci bili radnici. ${ }^{131}$

${ }^{128}$ Izlaganje Mijalka Todorovića, Zapisnik sa sednice Odbora za privredu održane 13, 14. i 16. aprila 1955, AJ, 130-831-1309.

${ }^{129}$ Zakon o doprinosu za stanbenu izgradnju, Službeni list FNRJ, 29. decembar 1955.

${ }^{130}$ S. Vujović, Ljudi i gradovi, Budva 1990, 50; Materijalni i društveni razvoj SFRJ 1947-1972, 282. V. i I Ginić, Dinamika i struktura gradskog stanovništva Jugoslavije. Demografski aspekti urbanizacije, Beograd 1967, 102-103.

${ }^{131}$ S. Vujović, Stambena kriza i ljudske potrebe, Sociologija, 4, 1979, 461; Đ. Đurović, Bespravna stambena izgradnja - jedna od karakteristika urbanog razvoja Beograda, Sociologija, 3-4, 1970, 499-503. V. i S. Šuvar, Između zaseoka i megalopolisa, Zagreb 1973, 157. 
Ivana Dobrivojević

DWELLING CONTITIONS IN YUGOSLAV CITIES 1945-1955

\section{Summary}

The hastened industrialisation in early socialist Yugoslavia led to de-agrarisation, mass migration and rapid urbanization. Around two million people moved from rural areas to the towns during the period 19451961. The abrupt population increase of towns was not accompanied by the adequate development of infrastructure. One of the most difficult problems was the dramatic shortage of flats. The combination of rapid population growth, slow building and poor quality of housing maintenance led to a constant decrease in the amount of urban dwelling space available to each person. During the mid 50-ties, it became clear that the housing policy has to be changed. The authorities came to the conclusion that the crisis can be solved only by large - scale individual ownership and investing a substantial portion of worker's wages into housing. However, despite the changes in the housing policy, the construction of the new flats stayed slow and insufficient. Thus, during the mid 60 -ties, Yugoslavia was at the very bottom of the European scale by the number of flats bulit per 1000 inhabitants. 